\title{
An Analysis of the Influence of the Titanium Compressor Wheel on the Dynamical Properties of the Particular Turbocharger Rotor
}

Luboš Smolík, Zdeňka Rendlová, Miroslav Byrtus

Department of Mechanics, University of West Bohemia, Univerzitni 22, 30614 Pilsen, Czech Republic. E-mail: carlist@kme.zcu.cz, zrendlov@kme.zcu.cz,mbyrtus@kme.zcu.cz

The trend towards using turbochargers in various engines continues. In some applications, including engines of light duty trucks, city buses and even tractors and harvesters, the warranty of long life is demanded because turbochargers are subject to high cyclic loading and on consequence the turbochargers can determine the lifetime of the whole engine. The replacement of the aluminium compressor wheel for a titanium one significantly improves the turbocharger lifetime, but since a titanium alloy has about $60 \%$ higher density than an aluminium alloy, the mass and the moments of inertia of the wheel increases, which further leads to changes in natural frequencies, rotor stability and power losses in bearings assuming the same bearing system as for the rotor with the aluminium wheel is employed. In this article the influence of the increased mass properties are discussed. AVL EXCITE and in-house developed model are used for the construction of Campbell diagrams and stability maps and for the obtaining of detailed information about the behaviour of the oil films in floating bearings.

Keywords: Turbocharger, Compressor Wheel, Campbell Diagram, Floating Bearings, Power Loss

\section{Acknowledgement}

The work presented in this article was supported by SGS-2013-036 project of University of West Bohemia. The usage of the AVL EXCITE software in the framework of the University Partnership Program of AVL List GmbH is greatly acknowledged.

\section{References}

[1] NAKAGAWA, Y. G., YOKOSHIMA, S., MASTUDA, K. (1992). Development of castable TiAl alloy for turbine components. In: Materials Science and Engineering: A, Vol. 153, Iss. 1-2, pp. 722-725. Elsevier, Amsterdam.

[2] SHOUREN, W., PEIQUAN, G., LIYING, Y. (2008). Centrifugal precision cast TiAl Turbocharger wheel using ceramic mold. In: Journal of Materials Processing Technology, Vol. 204, Iss. 1-3, pp. 492-497. Elsevier, Amsterdam.

[3] ENGELS, B. (2001). Lifetime Prediction for Turbocharger Compressor Wheels - Why Use Titanium? BorgWarner, Kirchheimbolanden.

[4] HAJŽMAN, H., ŠAŠEK, J., ZEMAN, V. (2009). Modelling of Flexible Rotor Vibrations in the Rotating Coordinate System. In: Modelling, Simulation and Control of Nonlinear Engineering Dynamical Systems (J. Awrejcewicz, (Ed.)), pp. 277-288. Springer, Berlin.

[5] BYRTUS, M., HAJŽMAN, M., ZEMAN, V. (2010). Dynamics of Rotating Machines. University of West Bohemia, Pilsen.

[6] OFFNER, G. et al. (2013). AVL EXCITE Power Unit v2013.2: Theory. AVL Group, Graz.

[7] SCHÄFER, H. N. (2012). Rotordynamics of Automotive Turbochargers. Springer, Berlin.

[8] MA, M. T., OFFNER, G., LOIBNEGGER, B., PRIEBSCH, H. H., McLUCKIE, I. R. W. (2004). A fast approach to model hydrodynamic behaviour of journal bearings for analysis of crankshaft and engine dynamics. In: Transient Processes in Tribology (G. Dalmaz et al., (Ed.)), Vol. 43, pp. 313-327. INSA, Lyon.

[9] PRAT, M., PLOURABÉ, F., LETALLEUR, N. (2002). Averaged Reynolds Equation for Flows between Rough Surfaces in Sliding Motion. In: Transport in Porous Media, Vol. 48, Iss. 3, pp. 291-313. Springer, Berlin.

[10] GREENWOOD, J. A., TRIPP, J. H. (1970). The Contact of Two Nominally Flat Rough Surfaces. In: Proceedings of the Institution of Mechanical Engineers, Vol. 185, pp. 625-633. Sage Publications, Thousand Oaks.

[11] JAVOROVA, J., ALEXANDROV, V., STANULOV, K. (2009). Static and Dynamic Performance of EHD Journal Bearings in Turbulent Flow. In: Proceedings of the $3^{\text {rd }}$ Int. Conference Power Transmissions '09, pp 453-460. Sofia Publications, Thessaloniki. 
[12] HANES, T., HVIZDOŠ, P., ŤAVOdOVÁ, M., KALINCOVÁ, D., HRICOVÁ, J., BEŇO, P. (2014). Coating Surface Roughness Measurement Made On Coining Dies. In: Manufactoring Technology, Vol. 14, No. 3, pp. 309317. J. E. Purkyně University, Ústí nad Labem

[13] BULÍN, R., HAJŽMAN, M. (2014). On the Modelling of Contact Forces in the Framework of Rigid Body Dynamics. In: Manufactoring Technology, Vol. 14, No. 2, pp. 136-141. J. E. Purkyně University, Ústí nad Labem.

Copyright $(\mathcal{C}$ 2015. Published by Manufacturing Technology. All rights reserved. 